All in Sync 
The publisher gratefully acknowledges the generous contribution to this book provided by the General Endowment Fund of the University of California Press Associates. 


\section{All in Sync}

How Music and Art Are Revitalizing American Religion

\section{Robert Wuthnow}


University of California Press

Berkeley and Los Angeles, California

University of California Press, Ltd.

London, England

(C) 2003 by The Regents of the University of California

Library of Congress Cataloging-in-Publication Data

Wuthnow, Robert.

All in sync : how music and art are revitalizing American religion / Robert Wuthnow.

p. $\quad \mathrm{cm}$.

Includes index.

ISBN 0-520-23769-2 (alk. paper)

I. United States-Religion. 2. Art and religion. I. Title.

BL2525.W853 2003

29I.3' $7^{\prime} 0973-\mathrm{dc} 2 \mathrm{I}$

2002067878

Manufactured in the United States of America
$\begin{array}{llllllllll}\text { I2 } & \text { II } & \text { IO } & 09 & 08 & 07 & 06 & 05 & 04 & 03\end{array}$
IO $\quad \begin{array}{lllllllll}9 & 8 & 7 & 6 & 5 & 4 & 3 & 2 & \text { I }\end{array}$

The paper used in this publication is both acid-free and totally chlorinefree (TCF). It meets the minimum requirements of ANSI/NISO Z39.48-I992 (R 1997) (Permanence of Paper). () 
Sometimes when we're singing and the spirit is moving, it's almost like the roof goes away and you can see the heavens. When we're all in sync, you can feel the spirit moving.

Church member 
This page intentionally left blank 